\title{
PENGARUH KUALITAS PRODUK DAN PEMASARAN DIGITAL TERHADAP KEPUTUSAN PEMBELIAN BIOSKOP CINEMA XXI (Studi Pada Mahasiswa di D.I Yogyakarta)
}

\author{
Markus Maria Rino \\ Lucia Nurbani Kartika \\ Fakultas Bisnis - Universitas Kristen Duta Wacana \\ Email korespondensi: ciakartika123@gmail.com
}

\begin{abstract}
ABSTRAK
Penelitian ini dilakukan dengan tujuan untuk mengetahui pengaruh kualitas produk dan pemasaran digital terhadap keputusan pembelian di Bioskop Cinema XXI. Penelitian ini dilakukan menggunakan pendekatan kuantitatif, sampel yang diambil sebanyak 100 mahasiswa yang pernah menonton film di Bioskop Cinema XXI. Metode pengumpulan data menggunakan kuesioner kemudian dianalisis secara deskriptif, analisis linear berganda, koefisien determinasi, uji F, dan uji t. Hasil analisis menunjukkan bahwa variabel pengaruh kualitas produk, pemasaran digital berpengaruh secara signifikan terhadap keputusan pembelian di Bioskop Cinema XXI. Maka dari itu, penting halnya untuk memperhatikan kualitas produk dan pemasaran digital untuk meningkatkan keputusan pembelian. Koefisien determinasi (adjusted R2) penelitian ini sebesar 0,782 yang berarti variabel dependen yaitu keputusan berkunjung dipengaruhi sebesar 78,2\% oleh variabel independen yaitu kualitas produk dan pemasaran digital. Sedangkan sisanya 21,8\% dipengaruhi oleh variabel lain yang tidak diteliti. Penelitian ini dilakukan pada bulan Januari 2021, berdasarkan penelitian ini variabel kualitas produk dan pemasaran digital secara simultan berpengaruh signifikan terhadap keputusan pembelian, sehingga Cinema XXI perlu terus meningkatkan kualitas dan menciptakan nilai tambah dan nilai bisnis di era bisnis digital saat ini.
\end{abstract}

Kata Kunci: kualitas produk, pemasaran digital, dan keputusan pembelian

\section{ABSTRACT}

This research was conducted with the aim to determine the influence of product quality and digital marketing on purchasing decisions at Bioskop Cinema XXI. This research was conducted by a quantitative approach, samples taken as many as 100 students for those who have attended Cinema XXI. The data collection methods were using questionnaire that would be analyzed descriptively, multiple linear analysis, coefficient of determination, $F$ test, and $t$ test. The results of the analysis showed that the product quality and digital marketing significantly influenced the purchase decision at Cinema XXI. Based on the results of data analysis, it showed that product quality was proven to have a positive and sifnificant effect indicated by the value $<0.05$, namely 0.000 , marketing digital was proven to have a positive and significant effect indicated by the value $<0.05$ which was 0.003 . The coefficient of determination (adjusted $\mathrm{R} 2$ ) of this study was 0.782 which meant the dependent variable which was the purchase decision was influenced $78.2 \%$ by the independent variables of product quality and digital marketing. Whereas, the remaining $21.8 \%$ was influenced by other variables that not examined. This research was done on January 2021. Based on the result of this research, the variables of product quality and digital marketing have simultaneously influenced on puchase decision, so they need to be maintained and even 
JRMB, Volume 16, No. 1, Juni 2021

better in the future in the middle of this digital business era. For the managerial implication, they have always to create added business values which will enhance customer purchase decision.

Keywords: product quality, digital marketing, and purchase decisions 


\section{PENDAHULUAN}

Perkembangan industri hiburan nasional saat ini semakin maju, karena ditunjang dengan perkembangan teknologi yang semakin pesat di era bisnis digital. Hal tersebut menimbulkan persaingan yang cukup ketat dalam memperebutkan pangsa pasar, tidak hanya mengandalkan produk yang berkualitas namun harus didukung oleh strategi dan upaya-upaya dalam memasarkan produk yang dihasilkan sehingga mempermudah konsumen dalam memilih produk sesuai dengan keinginan dan kebutuhannya. Bioskop di Indonesia, saat sebelum pandemi mengalami peningkatan jumlah penonton. Berdasarkan survei yang dilakukan oleh Badan Ekonomi Kreatif (BEKraf) dan Badan Pusat Statistik (BPS), peningkatan jumlah penonton bioskop dalam empat tahun terakhir mulai tahun 2015 hingga tahun 2019 semakin meningkat, peningkatannya sekitar 15\% setiap tahunnya. Badan Ekonomi Kreatif juga memprediksi untuk peningkatan jumlah penonton bioskop dapat dipastikan akan terus meningkat tiap tahunnya (filmindonesia.or.id,feb2019).

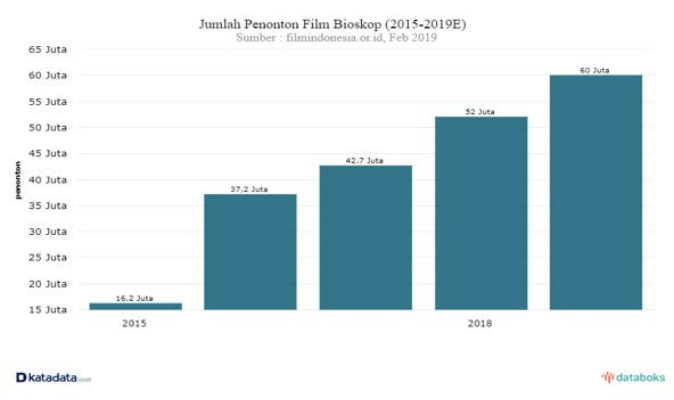

Sumber: Databoks.katadata.co.id

Kota Yogyakarta yang memiliki potensi besar dalam memanfaatkan perkembangan industri hiburan yaitu bioskop, dimanfaatkan oleh perusahaan yang terjun ke dalam industri hiburan. Persaingan pasar industri hiburan yang ketat, mengharuskan perusahaan dapat menunjukkan produk dan jasa yang berbeda dari pesaing lainnya agar mampu menciptakan keunggulan bersaing.

Peran kualitas produk sangat mempengaruhi keputusan pembelian, menurut Kotler dan Amstrong (2014 :11), kualitas produk merupakan kemampuan sebuah produk dalam memperagakan fungsinya, yang mencakup keseluruhan kinerja, reliabilitas, kesesuaian dengan spesifikasi, keistimewaan, durabilitas, dan estetika. Kemampuan kualitas produk tersebut dapat memberikan hasil atau kinerja yang sesuai dengan apa yang diharapkan pelanggan agar menimbulkan keputusan pembelian. Selain itu yang menjadi faktor penting dalam mempengaruhi keputusan pembelian yaitu pemasaran digital, yang mana merupakan penerapan teknologi-teknologi digital. Pemasaran digital di era digitalisasi bisnis saat ini sedang menjadi tren, dimana pemasar kini tidak lagi terbatas dengan bentuk-bentuk iklan yang menggunakan media konvensional seperti media cetak, tetapi sudah menerapkan pemasaran digital, konsumen mendapatkan kemudahan dalam mencari produk yang dibutuhkan untuk mencapai keputusan pembelian. (Chaffey, 2016).

Berdasarkan hal ini PT. Nusantara Sejahtera Raya sebagai perusahaan yang mengelola Bioskop Cinema 21, Cinema XXI, dan Premiere di beberapa kota di Indonesia khususnya di wilayah D.I Yogyakarta berusaha untuk memberikan yang terbaik kepada para pelanggannya melalui kualitas produk dan pemasaran digital. Saat ini bioskop menjadi salah satu hiburan alternatif yang sangat diminati, oleh karena itu Bioskop Cinema XXI memberikan produk yang berkualitas bagi konsumennya berupa teknologi Bioskop seperti Dolby Digital Cinema 3D dan aplikasi mobile ticketing untuk pemesanan tiket secara mudah (21cineplex.com) sehingga rumusan masalah dalam penelitian ini adalah apakah kualitas produk dan pemasaran digital mempengaruhi keputusan pembelian. 
Adapun tujuan dari penelitian ini adalah ingin mengetahui pengaruh variabel kualitas produk dan pemasaran digital terhadap keputusan pembelian di Bioskop Cinema XXI D.I Yogyakarta.

\section{KAJIAN LITERATUR DAN PENGEMBANGAN HIPOTESA}

\section{Kualitas Produk}

Menurut Schiffman dan Kanuk (2007), kualitas produk adalah kemampuan suatu perusahaan untuk memberikan identitas atau ciri pada setiap produknya sehingga konsumen dapat mengenali produk tersebut. Kemudian menurut Fandy Tjiptono (2000), kualitas produk adalah suatu produk, jasa, manusia, proses dan lingkungan yang memenuhi atau melebihi harapan. Pendapat tersebut dimaksudkan bahwa seberapa besar kualitas yang diberikan kemudian berhubungan dengan produk barang beserta faktor pendukungnya untuk memenuhi harapan penggunanya. Dapat diartikan bahwa semakin bagus kualitas produk yang dihasilkan maka konsumen akan semakin percaya sehingga akan mempengaruhi konsumen dalam keputusan pembelian.

\section{Pemasaran Digital}

Pengertian pemasaran digital merurut Urban (2004) adalah penggunaan internet beserta teknologi informasi untuk memperluas dan meningkatkan fungsi pemasaran tradisional. Kita juga bisa menyebut bahwa definisi tersebut menyatakan "interactive marketing". Sebelum melakukan kegiatan pemasaran digital ada beberapa hal yang harus diketehaui oleh pemasaran digital menurut Zaki dan Smitdev (2008) yaitu dengan menggunakan dan memanfaaatkan web, dengan tetap berorientasi pada prinsip pemasaran yang harus menerapkan tiga hal yakni tujuan pemasaran, pasar sasaran, dan produk atau jasa yang ditawarkan.

\section{Keputusan Pembelian}

Menurut Peter dan Olson (2000) keputusan pembelian adalah proses mengkombinasikan pengetahuan untuk mengevaluasi dua atau lebih perilaku alternatif dan memilih salah satu di antaranya. Keputusan pembelian menurut Schiffman dan Kanuk (2000) adalah pemilihan suatu tindakan dari dua pilihan alternatif atau lebih. Pranoto (2008), juga menjelaskan perilaku pengambilan keputusan oleh konsumen untuk melakukan pembelian produk atau jasa diawali dengan adanya kesadaran atas pemenuhan kebutuhan atau keinginan dan menyadari adanya masalah selanjutnya, maka konsumen akan melakukan beberapa tahap yang pada akhirnya sampai pada tahap pembelian. Menurut Kotler \& Amstrong (2001) keputusan pembelian juga menjadi tahap dalam proses pengambilan keputusan pembeli dimana konsumen benar-benar membeli. Pengambilan keputusan merupakan suatu kegiatan individu yang secara langsung terlibat dalam mendapatkan dan mempergunakan barang yang ditawarkan.

\section{Pengaruh Kualitas Produk terhadap Keputusan Pembelian}

Kualitas produk menjadi faktor penting yang menyebabkan barang atau hasil tersebut sesuai dengan tujuan, untuk apa barang itu dimaksudkan atau dibutuhkan. Apabila suatu produk dapat menjalankan fungsinya dengan baik termasuk dalam keseluruhan kemampuan kinerja, keistimewaan tambahan, kehandalan, kesesuaian spesifikasi, daya tahan dan estetika maka dengan demikian dapat disimpulkan bahwa kualitas produk yang baik akan mendorong keputusan pembelian konsumen Rambat dan Hambadi 2006, Alfatris dan Mahmud 2012, hipotesis yang dapat dirumuskan adalah

$\mathbf{H}_{1}$ : Diduga variabel Kualitas Produk memiliki pengaruh positif dan signifikan terhadap Keputusan Pembelian tiket Bioskop Cinema XXI Yogyakarta.

\section{Pengaruh Pemasaran Digital terhadap Keputusan Pembelian}

Hubungan pemasaran digital dengan keputusan pembelian diungkap oleh 
Pradiani 2017 bahwa sebagian besar pemasar sedikit demi sedikit mulai mengesampingkan model pemasaran tradional dan mulai mengembangkan model pemasaran modern yaitu pemasaran digital. Apabila model pemasaran digital seperti Search Engine Marketing (SEM), Online Public Relations, Online Partnerships, Interactive Advertising, Optin e-mail dan Viral marketing bekerja dengan baik maka akan mempengaruhi keputusan pembelian. Oleh karena itu dengan adanya pemasaran digital, konsumen dapat mengakses informasi Bioskop Cinema XXI dengan lebih mudah serta dapat membeli tiket Bioskop Cinema XXI secara praktis, cepat, nyaman dan lebih memudahkan dalam keputusan pembelian, hipotesis yang dapat dirumuskan adalah

$\mathbf{H}_{2}$ : Diduga variabel Pemasaran Digital memiliki pengaruh positif dan signifikan terhadap keputusan pembelian di Bioskop Cinema XXI Yogyakarta.

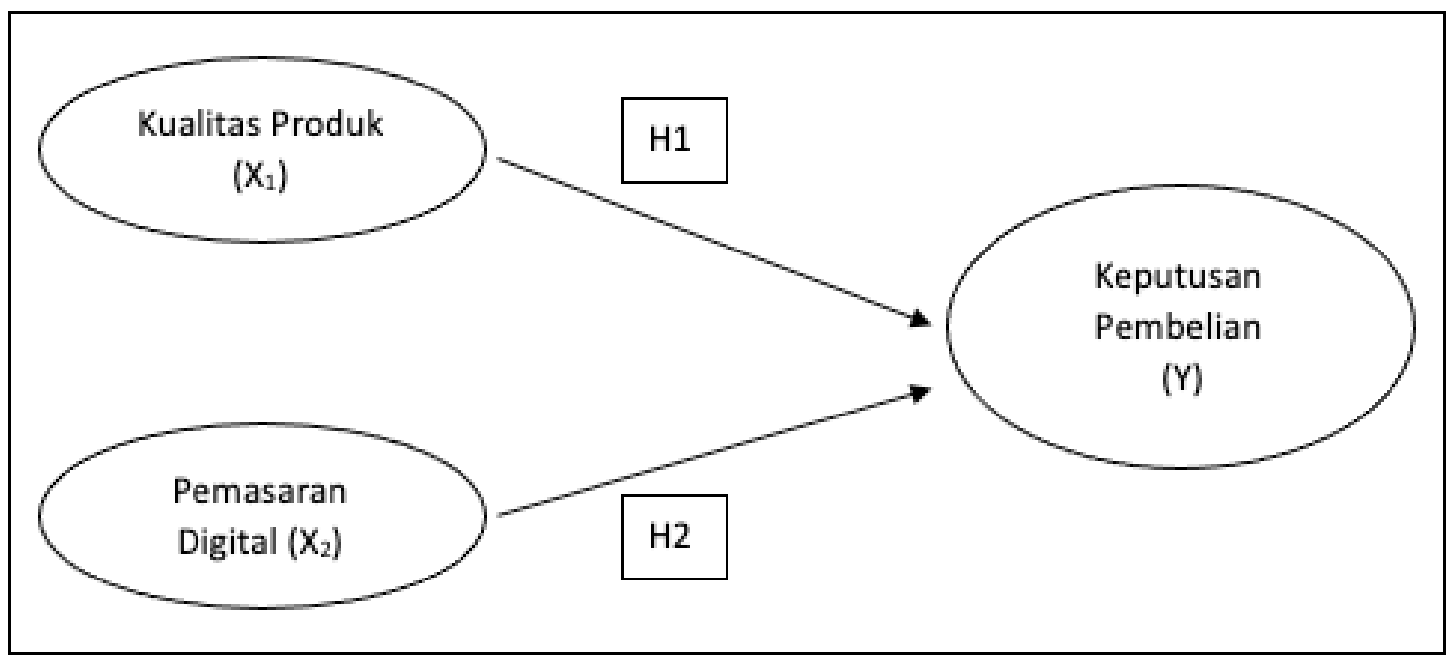

\section{METODE PENELITIAN}

Populasi dalam penelitian ini adalah seluruh mahasiswa di D.I Yogyakarta. Kriteria sampel dalam penelitian ini adalah mahasiswa yang pernah menonton di Bioskop Cinema XXI D.I. Yogyakarta. Teknik pengambilan sampel dalam penelitian ini adalah menggunakan teknik non-probability sampling dengan menggunakan purposive sampling Sugiyono (2015). Sampel dari penelitian ini berjumlah 100 orang, mahasiswa yang sudah pernah menonton film bioskop di XXI di D.I Yogyakarta, dengan cara menyebarkan kuesioner elektronik atau web survey melalui media google forms.

Pengolahan data dilakukan dengan menggunakan software SPSS 25 for MAC OS versi 25.0 dan uji instrumen penelitian yang digunakan ialah uji validitas, reliabilitas, kemudian dianalisis secara deskriptif, analisis linear berganda, koefisien determinasi (R2), uji F, dan uji t.

\section{Definisi Operasional Variabel Penelitian Kualitas Produk}

Kotler dan Amstrong (2014) mendefinisikan kualitas produk sebagai kemampuan sebuah produk dalam memperagakan fungsinya, hal itu termasuk keseluruhan durabilitas, reliabilitas, ketepatan, kemudahan pengoperasian dan reparasi produk juga atribut lainnya. Indikator dari kualitas produk tersebut meliputi: kinerja (kualitas gambar), keistimewaan tambahan (kualitas layar), kehandalan (kualitas suara), kesesuaian spesifikasi (kualitas film sesuai kebutuhan), daya tahan (kualitas tempat duduk yang ergonomis), estetika (kualitas 
ruangan yang eksklusif, nyaman, dan instagramable).

\section{Pemasaran Digital}

Chaffey (2016) mendefinisikan pemasaran digital sebagai penerapan dari internet serta teknologi-teknologi digital yang berkatian terhadap metode komunikasi tradisional untuk memperoleh tujuan pemasaran. Dengan mencakup indikator: Search Engine Marketing (SEM), Online Public Relations, Online Partnerships, Interactive Advertising, Optin e-mail, Viral Marketing.

\section{Keputusan Pembelian}

Menurut Kotler dan Amstrong (2008) keputusan pembelian merupakan suatu proses pengambilan keputusan akan pembelian yang mencakup penentuan apa yang akan dibeli atau tidak melakukan pembelian. Indikator dari keputusan pembelian adalah kemantapan pada sebuah produk, kebiasaan dalam membeli produk, memberikan rekomendasi kepada orang lain, dan melakukan pembelian ulang.

\section{Pengukuran Variabel}

Dalam penelitian ini, peneliti akan menyebarkan kuesioner dengan menggunakan skala penelitian untuk mengukur sikap dan pendapat melalui Skala Likert atau Likert Scale. Setiap pernyataan atau pertanyaan yang dikembangkan dari indikator dalam kuesioner penelitian. Setiap variabel diukur 4 butir pertanyaan. Likert yang digunakan:

\begin{tabular}{cc} 
Tabel 1. Tingkat Preferensi Jawaban Kuesioner \\
\hline Kategori & Skor (nilai) \\
\hline Sangat tidak setuju (STS) & Skor 1 \\
\hline Tidak setuju (TS) & Skor 2 \\
\hline Ragu-ragu (R) & Skor 3 \\
\hline Setuju (S) & Skor 4 \\
\hline Sangat Setuju (SS) & Skor 5
\end{tabular}

HASIL DAN PEMBAHASAN Uji Validitas

Uji validitas menunjukkan sejauh mana tingkat akurasi yang dipergunakan untuk mengukur pernyataan dalam kuestioner yang diukur.

Tabel 2. Hasil Uji Validitas

\begin{tabular}{llllc}
\hline Variabel & Butir & rhitung & rtabel & Uji Validitas \\
\hline Kualitas Produk & Kualitas Produk 1 & 0.907 & 0.239 & Valid \\
\hline & Kualitas Produk 2 & 0.844 & 0.239 & Valid \\
\hline & Kualitas Produk 3 & 0.918 & 0.239 & Valid \\
\hline & Kualitas Produk 4 & 0.885 & 0.239 & Valid \\
\hline & Kualitas Produk 5 & 0.870 & 0.239 & Valid \\
\hline Pemasaran Digital & Kualitas Produk 6 & 0.804 & 0.239 & Valid \\
\hline & Pemasaran Digital 1 & 0.831 & 0.239 & Valid \\
\hline & Pemasaran Digital 2 & 0.805 & 0.239 & Valid \\
\hline & Pemasaran Digital 3 & 0.866 & 0.239 & Valid \\
\hline & Pemasaran Digital 4 & 0.786 & 0.239 & Valid \\
\hline & Pemasaran Digital 5 & 0.662 & 0.239 & Valid \\
\hline Keputusan Pembelian & Pemasaran Digital 6 & 0.829 & 0.239 & Valid \\
\hline & Keputusan Pembelian 1 & 0.786 & 0.239 & Valid \\
\hline & Keputusan Pembelian 2 & 0.875 & 0.239 & Valid \\
\hline & Keputusan Pembelian 3 & 0.865 & 0.239 & Valid \\
\hline
\end{tabular}

Sumber: Data primer yang diolah (2021) 
Berdasarkan hasil pengujian validitas pada variabel kualitas produk, pemasaran digital, dan keputusan pembelian pada butir - butir pernyataan sebanyak 16 butir dalam kuesioner adalah valid karena nilai $r$ hitung lebih besar daripada nilai $r$ tabel yaitu 0.239 .

\section{Uji Reliabilitas}

Relibilitas merupakan sebuah pembuktian atau sebagai tanda bahwa adanya konsistensi dan kestabilan dari suatu skala, dalam penelitian ini peneliti menggunakan Cronbach Alpha untuk menguji reliabilitas. Dalam uji reliabilitas, nilai yang dikatakan reliabel atau handal apabila nilai Cronbach Alpha lebih besar atau sama dengan 0,6 (Nugriantoro:2007). Berdasarkan pengolahan data yang telah dilakukan hasil yang diperoleh adalah sebagai berikut:

Tabel 3. Hasil Uji Reliabilitas

\begin{tabular}{cccc}
\hline $\begin{array}{c}\text { Atribut Produk yang } \\
\text { diukur }\end{array}$ & Cronbach Alpha & $\begin{array}{c}\text { Nilai } \\
\text { Standar }\end{array}$ & Status \\
\hline Nilai total & 0.974 & 0.6 & Reliabel \\
\hline Kualitas Produk & 0.958 & 0.6 & Reliabel \\
\hline Pemasaran Digital & 0.918 & 0.6 & Reliabel \\
\hline Keputusan Pembelian & 0.911 & 0.6 & Reliabel \\
\hline
\end{tabular}

Sumber: Data primer yang diolah (2021)

Hasil uji reliabilitas baik secara keseluruhan atau masing-masing variabel menunjukkan bahwa nilai Cronbach's Alpha untuk penelitian lebih besar dari nilai standar yang telah ditetapkan yaitu sebesar 0.6. Maka dari itu, seluruh pertanyaan yang digunakan sebagai alat ukur dalam penelitian ini dapat dinyatakan reliabel.

\section{Analisis Deskriptif}

Dalam penelitian ini peneliti menggunakan analisis deskriptif dengan menggunakan persentase.

\section{Jenis Kelamin}

Jumlah responden berdasarkan jenis kelamin:

Tabel 4. Data Jenis Kelamin

\begin{tabular}{ccc}
\hline Jenis Kelamin & Frequency & Percent \\
\hline Laki-laki & 48 & $48 \%$ \\
\hline Perempuan & 52 & $52 \%$ \\
\hline Total & 100 & $100 \%$
\end{tabular}

Sumber: Data primer yang diolah (2021)

Berdasarkan data tabel di atas, menunjukan bahwa dari 100 responden

menunjukkan mayoritas jenis kelamin perempuan sebanyak 52\%.

Umur

Jumlah responden berdasarkan umur:

Tabel 5. Data Umur

\begin{tabular}{ccc}
\hline Umur & Frequency & Percent \\
\hline 17-20 Tahun & 22 & $22 \%$ \\
\hline 21-24 Tahun & 35 & $35 \%$ \\
\hline 25-28 Tahun & 25 & $25 \%$ \\
\hline 29-32 Tahun & 18 & $18 \%$ \\
\hline Total & 100 & $100 \%$
\end{tabular}

Sumber : Data primer yang diolah (2021) 
JRMB, Volume 16, No. 1, Juni 2021

Dari data tabel diatas, diketahui Universitas bahwa rentan usia responden yang Jumlah responden berdasarkan tertinggi yaitu memiliki rentan umur 21-24 Universitas:

Tabel 6. Data Asal Universitas

\begin{tabular}{ccc}
\hline Universitas & Frequency & Percent \\
\hline UAJY & 18 & $18 \%$ \\
\hline UGM & 24 & $24 \%$ \\
\hline UAD & 15 & $15 \%$ \\
\hline STIKES Bethesda & 9 & $9 \%$ \\
\hline ISI & 10 & $10 \%$ \\
\hline UMY & 12 & $12 \%$ \\
\hline STIPRAM & 12 & $12 \%$ \\
\hline Total & 100 & $100 \%$ \\
\hline
\end{tabular}

Sumber: Data primer yang diolah (2021)

Dari data tabel diatas, dapat Tahun Masuk

diketahui bahwa persentase tertinggi Jumlah responden berdasarkan tahun responden adalah mahasiswa dari UGM masuk:

sebanyak $24 \%$.

Tabel 7. Data Tahun Masuk

\begin{tabular}{ccc}
\hline Tahun Masuk & Frequency & Percent \\
\hline $\mathbf{2 0 1 5}$ & 10 & $10 \%$ \\
\hline $\mathbf{2 0 1 6}$ & 12 & $12 \%$ \\
\hline $\mathbf{2 0 1 7}$ & 25 & $25 \%$ \\
\hline $\mathbf{2 0 1 8}$ & 18 & $18 \%$ \\
\hline $\mathbf{2 0 1 9}$ & 26 & $26 \%$ \\
\hline $\mathbf{2 0 2 0}$ & 9 & $9 \%$ \\
\hline Total & 100 & $100 \%$ \\
\hline
\end{tabular}

Sumber: Data primer yang diolah (2021)

Dari data tabel diatas, dapat diketahui bahwa persentase tertinggi responden berdasarkan tahun masuk kuliah tertinggi adalah angkatan 2019 sebanyak $26 \%$.

\section{Menempuh Program Pendidikan}

Jumlah responden berdasarkan program pendidikan.

Tabel 8. Data Program Pendidikan

\begin{tabular}{ccc}
\hline Program Pendidikan & Frequency & Percent \\
\hline S1 & 38 & $38 \%$ \\
\hline S2 & 24 & $24 \%$ \\
\hline S3 & 9 & $9 \%$ \\
\hline D3 & 28 & $28 \%$ \\
\hline Total & 100 & $100 \%$
\end{tabular}

Sumber: Data primer yang diolah (2021)

Dari data tabel diatas, dapat diketahui bahwa persentase tertinggi responden dengan menempuh program pendidikan S1 sebanyak 38\%.

Rekan Berkunjung

Jumlah responden berdasarkan rekan berkunjung: 
Tabel 9. Data Rekan Berkunjung

\begin{tabular}{ccc}
\hline Rekan Berkunjung & Frequency & Percent \\
\hline Teman & 39 & $39 \%$ \\
\hline Pacar & 34 & $34 \%$ \\
\hline Saudara & 20 & $20 \%$ \\
\hline Orang tua & 7 & $7 \%$ \\
\hline Total & 100 & $100 \%$
\end{tabular}

Sumber: Data primer yang diolah (2021)

Dari data tabel diatas, dapat ke Bioskop XXI yaitu teman dengan diketahui bahwa persentase tertinggi presentase $39 \%$. responden berdasarkan rekan berkunjung

\section{Jenis Film}

Jumlah responden berdasarkan jenis film:

Tabel 10. Jenis Film yang Ditonton

\begin{tabular}{ccc}
\hline Jenis Film & Frequency & Percent \\
\hline Horor & 23 & $23 \%$ \\
\hline Aksi & 28 & $28 \%$ \\
\hline Drama & 10 & $10 \%$ \\
\hline Komedi & 20 & $20 \%$ \\
\hline Petualangan & 10 & $10 \%$ \\
\hline Fantasi Musikal & 9 & $9 \%$ \\
\hline Total & 100 & $100 \%$
\end{tabular}

Sumber: Data primer yang diolah (2021)

Dari data tabel diatas, dapat diketahui bahwa persentase tertinggi responden berdasarkan jenis film yang banyak ditonton adalah aksi sebanyak $28 \%$.

\section{Analisis regresi linear berganda}

Analisis regresi linear berganda adalah pengaruh dari dua atau lebih variabel independen (variabel bebas atau $\mathrm{X}$ ) terhadap variabel dependent (variabel terikat atau Y).

Tabel 11. Hasil Regresi Linear Berganda

\begin{tabular}{|c|c|c|c|c|c|c|c|}
\hline \multirow[b]{2}{*}{ Model } & \multicolumn{2}{|c|}{$\begin{array}{l}\text { Unstandardized } \\
\text { Coefficients }\end{array}$} & \multirow{2}{*}{$\begin{array}{c}\begin{array}{c}\text { Standardized } \\
\text { Coefficients }\end{array} \\
\text { Beta }\end{array}$} & \multirow[b]{2}{*}{$t$} & \multirow[b]{2}{*}{ Sig. } & \multicolumn{2}{|c|}{$\begin{array}{c}\text { Collinearity } \\
\text { Statistics }\end{array}$} \\
\hline & $\mathbf{B}$ & Std. Error & & & & Tolerance & VIF \\
\hline (Constant) & -1.372 & .965 & & -1.422 & .158 & & \\
\hline Kualitas produk & .452 & .085 & .576 & 5.320 & .000 & .187 & 5.338 \\
\hline Pemasaran digital & .273 & .089 & .332 & 3.063 & .003 & .187 & 5.338 \\
\hline
\end{tabular}

Sumber: Data primer yang diolah (2021)

Dari analisis regresi pada tabel 4.15 mendapat hasil sebagai berikut :

$\mathrm{Y}=-1.372+0.452$ Kualitas Produk +0.273 Pemasaran Digital.

Berdasarkan persamaan regresi tersebut diketahui bahwa nilai Y (keputusan pembelian) dipengaruhi oleh variabel $\mathrm{X}$ yaitu kualitas produk (X1) mempunyai nilai positif dan signifikan sebesar 0.452 , pemasaran digital (X2) mempunyai nilai positif dan signifikan sebesar 0.273 . Apabila masing-masing indikator yang ada dalam masing-masing variabel semakin sesuai dengan harapan konsumen maka keputusan pembelian konsumen semakin meningkat.

\section{Koefisien Determinasi}

$$
\text { Koefisien Determinasi }
$$
digunakan untuk melihat seberapa besar pengaruh variabel kualitas produk dan pemasaran sebagai variabel independen 
JRMB, Volume 16, No. 1, Juni 2021

terhadap keputusan pembelian sebagai variabel dependen.

Tabel 12. Koefisien Determinasi

\begin{tabular}{lrrrrr}
\hline Model & \multicolumn{1}{l}{ R } & \multicolumn{2}{c}{ R Square } & Adjusted R Square & \multicolumn{2}{c}{ Std. Error of the Estimate } \\
\hline 1 & $.887^{\mathrm{a}}$ & .787 & .782 & 1.589 \\
\hline
\end{tabular}

Sumber: Data primer yang diolah (2021)

Nilai koefisien determinasi adalah sebesar 0.787 artinya sumbangan variabel kualitas produk, dan pemasaran digital dalam mempengaruhi keputusan pembelian adalah sebesar 78,2\%. Sisanya sebesar 21,8\% dipengaruhi variabel lain yang tidak diteliti, misal seperti persepsi harga dan citra merek.

\section{Uji signifikan secara simultan (Uji F)}

Uji F digunakan dalam penelitian ini untuk dapat mengetahui seberapa besar tingkat signifikansi pengaruh variabelvariabel independen yang dimasukkan dalam model mempunyai pengaruh secara simultan atau bersama - sama terhadap variabel dependen.

Tabel 13. Hasil Uji F

\begin{tabular}{lcrrrr}
\hline Model & Sum of Squares & \multicolumn{1}{c}{ Df } & Mean Square & F & \multicolumn{1}{c}{ Sig. } \\
\hline Regression & 903.653 & 2 & 451.826 & 178.990 & $.000^{\mathrm{b}}$ \\
Residual & 244.857 & 97 & 2.524 & & \\
Total & 1148.510 & 99 & & & \\
\hline
\end{tabular}

Sumber: Data primer yang diolah (2021)

Berdasarkan hasil uji F disimpulkan

bahwa variabel kualitas produk, dan pemasaran digital secara simultan berpengaruh signifikan terhadap keputusan pembelian Bioskop Cinema XXI. Dengan demikian, hipotesis yang diajukan dapat diterima atau terbukti kebenarannya.

\section{Uji t}

Uji Statistik $t$ pada dasarnya menunjukkan seberapa jauh pengaruh satu variabel independen secara individual dalam menerangkan variasi variabel dependen (Ghozali, 2006: 84).

Tabel 14. Hasil Uji t

\begin{tabular}{|c|c|c|c|c|c|}
\hline \multirow[b]{2}{*}{ Model } & \multicolumn{2}{|c|}{ Unstandardized Coefficients } & \multirow{2}{*}{$\begin{array}{c}\begin{array}{c}\text { Standardized } \\
\text { Coefficients }\end{array} \\
\text { Beta }\end{array}$} & \multirow[b]{2}{*}{$\mathbf{t}$} & \multirow[b]{2}{*}{ Sig. } \\
\hline & B & Std. Error & & & \\
\hline (Constant) & -1.372 & .965 & & -1.422 & .158 \\
\hline Kualitas Produk & .452 & .085 & .576 & 5.320 & .000 \\
\hline Pemasaran Digital & .273 & .085 & .332 & 3.063 & .003 \\
\hline
\end{tabular}

Sumber: Data primer yang diolah (2021)

Berdasarkan analisis yang telah dilakukan, diperoleh nilai probabilitas (nilai signifikan) variabel kualitas produk 0.000, dan pemasaran digital 0.003,

\section{Pembahasan Hasil}

\section{Pengaruh Variabel Kualitas Produk Terhadap Keputusan Pembelian}

Berdasarkan hasil, variabel kualitas produk secara parsial dinyatakan berpengaruh secara signifikan terhadap keputusan pembelian pada Bioskop XXI di D.I Yogyakarta. Dimana nilai probabilitas keputusan pembelian adalah sebesar 0.000 lebih kecil dari taraf signifikan yang dimana nilai signifikan yang paling berpengaruh adalah variabel kualitas produk.

berjumlah 0.05. Hal ini menunjukkan bahwa dalam industri hiburan seperti film, konsumen pasti lebih berfokus pada kualitas film dengan gambar yang jelas dan tajam, kualitas suara yang jernih, tempat duduk yang ergonomis dan memiliki kualitas ruang yang eksklusif yang akan membuat suasana ruangan menjadi nyaman sehingga bagi konsumen, kualitas produk merupakan faktor yang 
utama untuk menjadi bahan pertimbangan dalam membuat keputusan. Hasil penelitian ini mendukung penelitian sebelumnya yang dilakukan oleh Ridhani Sabrina (2016) tentang Pengaruh Lokasi, Persepsi Harga, dan Kualitas Produk Terhadap Keputusan Pembelian (Studi pada Bioskop Empire XXI Yogyakarta). Hasil penelitian menunjukkan bahwa kualitas produk mempunyai pengaruh positif dan signifikan terhadap keputusan pembelian.

\section{Pengaruh Variabel Pemasaran Digital Terhadap Keputusan Pembelian}

Berdasarkan hasil, variabel pemasaran digital secara parsial dinyatakan berpengaruh secara signifikan terhadap keputusan pembelian pada Bioskop XXI di D.I Yogyakarta. Dimana nilai probabilitas keputusan pembelian adalah sebesar 0.003 lebih kecil dari taraf signifikan yang berjumlah 0.05. Di era digitalisasi saat ini konsumen pasti mencari kemudahan, kenyamanan dan kecepatan dalam mencari informasi dan memberli suatu produk, oleh karena itu pemasaran digital merupakan faktor penentu bagi konsumen untuk membuat keputusan pembelian. Responden mahasiswa dalam hal ini lebih memilih pemasaran yang praktis, cepat, mudah diakses dan nyaman dalam membuat keputusan pembelian. Hasil penelitian ini mendukung penelitian sebelumnya yang dilakukan oleh Ridhani Afan Ehamzah Rifai Mardiastika (2017) tentang Pengaruh Citra Merek, Pemasaran Digital, dan Kualitas Produk Terhadap Keputusan Pembelian Ulang Konsumen Bioskop Cinema XXI Yogyakarta. Hasil penelitian menunjukkan bahwa Pemasaran Digital mempunyai pengaruh positif dan signifikan terhadap keputusan pembelian.

\section{Kesimpulan}

Berdasarkan hasil analisis data dan pembahasan yang dilakukan dalam penelitian ini, maka dapat disimpulkan bahwa:

Tabel 14. Hasil Uji Hipotesis

\begin{tabular}{ccc}
\hline Hipotesis & Pernyataan & Hasil \\
\hline H1 & Diduga variabel & Berpengaruh \\
& Kualitas Produk & \\
& berpengaruh secara & \\
& terhadap Keputusan & \\
& Pembelian di Bioskop & \\
& Cinema XXI. & Berpengaruh \\
& Diduga variabel & \\
& Pemasaran Digital & \\
& berpengaruh secara & \\
& positif dan signifikan & \\
& terhadap Keputusan & \\
& Pembelian di Bioskop & \\
& Cinema XXI. & \\
\end{tabular}

Sumber: Data primer yang diolah (2021)

Hasil penelitian menunjukkan bahwa dari dua hipotesis yang dirancang, keduanya diterima. Dari pengujian seluruh hipotesis tersebut dapat disimpulkan bahwa kualitas produk berpengaruh positif signifikan terhadap keputusan pembelian. Sedangkan pemasaran digital juga berpengaruh positif signifikan terhadap keputusan pembelian. Karena semakin tinggi tingkat kualitas produk dan pemasaran digital, maka akan meningkatkan keputusan pembelian konsumen di Bioskop XXI di D.I Yogyakarta. 


\section{Saran}

Pada penelitian ini, peran kualitas produk dan pemasaran digital telah memberikan pengaruh positif terhadap keputusan pembelian, namun perusahaan

\section{REFERENSI}

Andrian, P. (2008). The Essence of Service Marketing (Pemasaran Jasa).

Assauri, S. (2004). Manajemen Produksi dan Operasi. Jakarta: Lembaga Fakultas Ekonomi UI.

Buchari, A. (2009). Manajemen Pemasaran dan Pemasaran Jasa. Bandung: Alfabeta.

Danang, S. (2014). Konsep Dasar Riset Pemasaran \& Perilaku Konsumen. Yogyakarta: CAPS.

Ghozali, I. (2006). Aplikasi Analisis Multivariate dengan Program SPSS. Semarang: Badan Penerbit Universitas Diponegoro.

Ghozali, I. (2009). Aplikasi Analisis Multivariate dengan Program SPSS, Edisi Keempat. Semarang: Badan Penerbit Universitas Diponegoro.

Ghozali, I. (2016). Aplikasi Analisis Multivariete Dengan Program IBM SPSS 23 (Edisi 8). Cetakan ke VIII. Semarang: Badan Penerbit Universitas Diponegoro.

Gitosudarmo, I. (2014). Manajemen Pemasaran. Cetakan Ketiga, Edisi Kedua. Yogyakarta: BPFE.

Kotler, P., \& Armstrong, G. (2012). Prinsip-Prinsip Pemasaran Jilid 1. Jakarta: Erlangga.

Kotler, P. (2005). Manajemen Pemasaran, Edisi XI. Jilid 2. Jakarta: PT. Indeks Kelompok Gramedia .

Kotler, P. (2007). Marketing Management, Jilid 2, Edisi 12. New Jersey: PT. Indeks.

Kotler, P. (2008). Manajemen Pemasaran, Edisi Tiga Belas, Terjemahan Bob Sabran. Jakarta: Erlangga. harus tetap harus meningkatkan inovasi dan nilai tambah bisnis melalui indikatorindikator yang ada demi meningkatkan keputusan pembelian pada konsumen di era

digitalisasi.

Kotler, P., \& Armstrong, G. (2001). Prinsip-Prinsip Pemasaran, Edisi Dua Belas. Jakarta:: Erlangga.

Kotler, P., \& Armstrong, G. (2006). Prinsip-Prinsip Pemasaran. Jakarta: Erlangga.

Kotler, P., \& Armstrong, G. (2008). Prinsip-Prinsip Pemasaran Edisi 12 Jilid 1. Jakarta: Erlangga.

Kotler, P., \& Keller, K. (2009). Marketing Management, Thirteenth Edition, Diterjemahkan Oleh Bob Sabran Dengan Judul Manajemen Pemasaran Edisi Ketiga Belas Jilid 1. Index.

Maharani, A. (2018). Analisis Pengaruh Kualitas Produk Terhadap Keputusan Pembelian pada Bioskop XXI Paragon Semarang.

Mardiastika, E. (2017) Pengaruh Citra Merek, Pemasaran Digital, dan Kualitas Produk Terhadap Keputusan Pembelian Ulang Konsuemen Bioskop Cinema XXI Yogyakarta.

Paul, J., \& Jerry, C. (2000). Consumer Behavior: Perilaku Konsumen dan Strategi Pemasaran. Terjemahan. Jakarta: Erlangga.

Pranoto , B. (2008). Pengaruh Harga dan Kualitas Produk Terhadap Keputusan Konsumen Membeli Kendaraan Bermotor. Jurnal Ilmiah Faktor Extra, Vol.1 No. 2 September 2008.

Sabrina, R. (2016). Pengaruh Lokasi, Persepsi Harga, dan Kualitas Produk Terhadap Keputusan Pembelian (Studi pada Bioskop Empire XXI Yogyakarta). 
Sugiyono. (2004). Metode Penelitian Bisnis. Bandung: Alfabeta.

Sugiyono. (2009). Propobality Sampling. Bandung: Alfabeta.

Sugiyono. (2009). Statistika Untuk Penelitian. Bandung: Alfabeta.

Sugiyono. (2010). Metode Penelitian Kuantitatif Kualitatif \& $R \& D$. Bandung: Alfabeta.

Sugiyono. (2011). Metode Penelitian Kuantitatif, Kualitatif dan $R \& D$. Bandung: Alfabeta.

Sugiyono. (2013). Metode Penelitian Kuantitatif, Kualitatif \& R\&D. Bandung: Alfabeta.
Sugiyono. (2015). Metode Penelitian dan Pengembangan Untuk Bidang Pendidikan, Manajemen, Sosial, dan Teknik. Bandung: Alfabeta.

Suryohadibroto, I., \& Prakoso, D. (1995). Surat Berharga Alat Pembayaran Dalam Masyarakat Modern. Jakarta: Rineka Cipta.

Tjiptono, F. (2002). Sistem Pemasaran. Yogyakarta: CV. Andi.

Tjiptono, F. (2014). Pemasaran JasaPrinsip, Penerapan dan Penelitian. Yogyakarta: CV. ANDI. 